\title{
NUMERICAL MODELING AND ANALYSIS OF HTM-FREE HETEROJUNCTION SOLAR CELL USING SCAPS-1D
}

\author{
DEli Danladi ${ }^{a}$,*, Alhassan Shuaibu ${ }^{\mathrm{b}}$, Muhammad Sani Ahmad ${ }^{\mathrm{b}}$ Jamila Tasiu $^{\mathrm{b}}$ \\ ${ }^{a}$ Department of Physical Sciences, Greenfield University, Kaduna, Nigeria \\ ${ }^{b}$ Department of Physics, Kaduna State University, Kaduna, Nigeria \\ *Coresponding Author: danladielibako@gmail.com, +2348063307256 \\ Received January 19, 2021; revised March 27, 2021; accepted April 10, 2021
}

In this research paper, a HTM-free perovskite solar cell (PSC) structure with Titanium $\left(\mathrm{TiO}_{2}\right)$, methyl ammonium lead triiodide $\left(\mathrm{CH}_{3} \mathrm{NH}_{3} \mathrm{PbI}_{3}\right)$ and platinum (pt) as electron transport material (ETM), photon harvester and metal back contact is proposed. Solar Cell Capacitance Simulator (SCAPS-1D) program was used to implement the model and simulation. Effect of parameters such as thickness of ETM, thickness of absorber, doping concentration of ETM \& absorber and electron affinity (EA) of ETM were investigated systematically. From the obtained results, it was found that the parameters affect the performance of the solar cell. When the thickness of ETM was varied from 0.02 to $0.10 \mu \mathrm{m}$. The results show that photovoltaic parameters decrease with the thickness increase. When the thickness of the absorber was varied from 0.1 to $1.0 \mu \mathrm{m}$, the optimized value was found at thickness of $0.4 \mu \mathrm{m}$. When the doping concentration of absorber and EMT were varied from $10^{10}-10^{17} \mathrm{~cm}^{-3}$ and from $10^{15}-10^{20} \mathrm{~cm}^{-3}$, the highest values of PCEs were obtained at $10^{16} \mathrm{~cm}^{-3}$ and $10^{20} \mathrm{~cm}^{-3}$ for Absorber and ETM. Also when the EA was varied in the range of $3.7 \mathrm{eV}$ to $4.5 \mathrm{eV}$, the optimized value was at $3.7 \mathrm{eV}$. Upon optimization of the above mentioned parameters, power conversion efficiency (PCE) was found to be $25.75 \%$, short circuit current density $\left(\mathrm{J}_{\mathrm{sc}}\right) 23.25 \mathrm{mAcm}^{-2}$, open circuit voltage $\left(\mathrm{V}_{\mathrm{oc}}\right) 1.24 \mathrm{~V}$ and fill factor $(\mathrm{FF}) 89.50 \%$. The optimized result shows an improvement of $\sim 1.95$ times in PCE, $\sim 1.06$ times in $\mathrm{J}_{\mathrm{sc}}, \sim 1.44$ times in $\mathrm{V}_{\mathrm{oc}}$ and $\sim 1.28$ times in FF as compared to the initial device with the following parameters, $\mathrm{PCE}=13.22 \%, \mathrm{~J}_{\mathrm{sc}}=21.96 \mathrm{mAcm}^{-2}, \mathrm{~V}_{\mathrm{oc}}=0.86 \mathrm{~V}$ and $\mathrm{FF}=69.94 \%$.

KEYWORDS: perovskite solar cells, HTM free, device modeling, simulation, band gap offset

Recently, organic-inorganic metal halide perovskite solar cells have taken the renewable energy community by storm and subsequently gained attention of several world's researchers due to its high performance and low cost. Several advantages of perovskite absorber have made it a choice of candidate for application photovoltaic structures, among which include, tuned band gap, small exciton energy, excellent bipolar carrier transport, long electron-hole diffusion, and amazingly high tolerance to defects [1-7]. The properties exhibited by this material in solar cells results to enhanced power conversion efficiency from $3.9 \%$ [8] to over $25 \%$ [9]. However, some draw backs such as instability, electron transport resistance between $\mathrm{TiO}_{2}$ and perovskite absorber and the use of costly hole transport material (HTM) (such as spiro-Omeotad) has prevented its outdoor usage. Therefore, the use of readily available and stable materials having high hole mobility with simple route of synthesis is desirable [10-12].

A report on perovskite solar cell without HTM was demonstrated firstly by Etgar et al. [13], where the perovskite absorber functions as a transporter of hole and harvester of photon energy simultaneously and results to a PCE of 5\%. The results demonstrate simplicity and high reduction in cost of fabrication and a relatively improved stability as a result of HTM elimination. Also, in 2014, Li et al. [14] followed the same route by replacing metal back contact with laminated carbon nanotubes (CNTs) to collect holes from absorber and block electrons from ETM and results to a PCE of $6.87 \%$. Eli et al. [9] developed a PSC without HTM with elcocarb as metal back contact to collect hole and realized a PCE of $3.80 \%$.

Recently a PCE of $10.95 \%$ with about $95 \%$ stability of their initial efficiency after being exposed to air (relative humidity of 25-35\%) for 20 days, was demonstrated by Zhang et al [15]. In a simulation studies by Lin et al [16], a PCE of $15.02 \%$ was obtained with a structure without HTM and ZnO as ETM. Theoretical studies carried out by Wang and group [17] shows that the careful selection of thickness of the absorber and p-type doping were crucial to the PCE of the HTM-free PSCs.

The HTM-free PSC is a simple and promising way to realize good PCE but some factors deter its practical use. PSC devices mostly make use of costly gold $(\mathrm{Au})$ as a back contact. The Au metal contact is not only expensive but the process of synthesis and development require the use of high-technology (such as high-vacuum evaporation technique). Platinum metal, with the work function of 5.93 [18], has been applied in perovskite solar cells with HTM and without HTM, but the PV parameters were of poor values for $\operatorname{HTM}\left(\mathrm{Jsc}=7.17 \mathrm{mAcm}^{-2}, \mathrm{Voc}=0.69, \mathrm{FF}=62.62\right.$ and $\left.\mathrm{PCE}=3.08 \%\right)$. And for the device without HTM, the PV parameters are $\mathrm{Jsc}=20.58 \mathrm{mAcm}^{-2}$, Voc $=1.006, \mathrm{FF}=71.07$ and $\mathrm{PCE}=14.72 \%$.

To realize higher photovoltaic parameters and proper optimized architecture in HTM-free PSC, systematic understanding of the operational mechanism needs to be uncovered. Yet till now, numerical modeling and simulation of the HTM-free PSCs with platinum metal contact and $\mathrm{TiO}_{2} \mathrm{ETM}$ has seldom been reported. Platinum metal has a high work function and good chemical stability. In view of that, this research paper, attempts to present a detailed numerical modeling and simulation of HTM-free PSCs based on solar cell capacitance simulator (SCAPS) software to systematically study the influence of some material (such as thickness of ETM, thickness of absorber layer, doping concentration of 
ETM, doping concentration of absorber layer, electron affinity of ETM etc), with the goal of uncovering the hidden mechanism for PCE improvement.

\section{METHOD AND METHODOLOGY}

The nature of the defect is set as Gaussian and defect density is set as $1 \times 10^{18} \mathrm{~cm}^{-3}[19,20]$. Table 1 shows the defect parameters which are used in the simulation. Basic parameters for each material used in the simulation are summarized in Table 2. Thermal velocities of hole and electron are selected as $10^{7} \mathrm{cms}^{-1}$ [19-22]. The optical reflectance is considered to be zero at the surface and at each interface [19]. Parameters are optimized in the study by using control variable method. The initial total defect density of the absorber layer is assumed to be $2.5 \times 10^{13} \mathrm{~cm}^{-3}$. Neutral Gaussian distribution defect is selected in the absorber layer and characteristic energy is set to be $0.1 \mathrm{eV}$ [19]. One defect interface is inserted for carrier recombination. The interface defect layer (IDL) is introduced in the $\mathrm{TiO}_{2} / \mathrm{CH}_{3} \mathrm{NH}_{3} \mathrm{PbI}_{3}$ interface to investigate the influence of interfacial recombination on the photovoltaic performance. The work functions of the front contact and back contact are $4.40 \mathrm{eV}$ and $5.93 \mathrm{eV}$ respectively [18,23]. A working temperature of 300K, solar spectrum AM1.5 and a Scanning voltage of $0-1.3 \mathrm{~V}$ were used for all simulations.

Table 1. Defect parameters of interfaces and absorber [19,20,23]

\begin{tabular}{|l|c|c|}
\hline \multicolumn{1}{|c|}{ Parameters } & $\mathrm{CH}_{3} \mathrm{NH}_{3} \mathrm{PbI}_{3}$ & $\mathrm{TiO}_{2} / \mathrm{CH}_{3} \mathrm{NH}_{3} \mathrm{PbI}_{3}$ interface \\
\hline Defect type & Neutral & Neutral \\
Capture cross section for electrons $\left(\mathrm{cm}^{2}\right)$ & $2 \times 10^{-14}$ & $2 \times 10^{-14}$ \\
Capture cross section for holes $\left(\mathrm{cm}^{2}\right)$ & $2 \times 10^{-14}$ & $2 \times 10^{-14}$ \\
Energetic distribution & $\mathrm{Gaussian}$ & Single \\
Energy level with respect to Ev $(\mathrm{eV})$ & 0.500 & 0.650 \\
Characteristic energy $(\mathrm{eV})$ & 0.1 & 0.1 \\
Total density $\left(\mathrm{cm}^{-3}\right)$ & $1 \times 10^{15}-1 \times 10^{19}$ & $1 \times 10^{17}$ \\
\hline
\end{tabular}

Table 2. Simulation parameters of PSCs devices [19, 20,23,24]

\begin{tabular}{|c|c|c|c|}
\hline Parameters & FTO & ETM $\left(\mathrm{TiO}_{2}\right)$ & Absorber \\
\hline Thickness $(\mu \mathrm{m})$ & 0.4 & 0.05 & 0.45 \\
\hline Band gap energy Eg $(\mathrm{eV})$ & 3.5 & 3.26 & 1.55 \\
\hline Electron affinity $\chi(\mathrm{eV})$ & 4.0 & 4.2 & 3.90 \\
\hline Relative permittivity er & 9 & 10 & 6.50 \\
\hline Effective conduction band density $\mathrm{Nc}\left(\mathrm{cm}^{-3}\right)$ & $2.2 \times 10^{18}$ & $2.2 \times 10^{28}$ & $2.2 \times 10^{18}$ \\
\hline Effective valance band density $\mathrm{Nv}\left(\mathrm{cm}^{-3}\right)$ & $2.2 \times 10^{18}$ & $2.2 \times 10^{18}$ & $2.2 \times 10^{18}$ \\
\hline Electron mobility $\mu \mathrm{n}\left(\mathrm{cm}^{2} \mathrm{~V}^{-1} \mathrm{~s}^{-1}\right)$ & 20 & 20 & 2 \\
\hline Hole mobility $\mu \mathrm{p}\left(\mathrm{cm}^{2} \mathrm{~V}^{-1} \mathrm{~s}^{-1}\right)$ & 10 & 10 & 2 \\
\hline Donor concentration $\mathrm{N}_{\mathrm{D}}\left(\mathrm{cm}^{-3}\right)$ & $1 \times 10^{19}$ & $1 \times 10^{17}$ & 0 \\
\hline Acceptor concentration $\mathrm{N}_{\mathrm{A}}\left(\mathrm{cm}^{-3}\right)$ & 0 & 0 & $1 \times 10^{13}$ \\
\hline Defect density $\mathrm{N}_{\mathrm{t}}\left(\mathrm{cm}^{-3}\right)$ & $1 \times 10^{15}$ & $1 \times 10^{15}$ & $2.5 \times 10^{13}$ \\
\hline
\end{tabular}

RESULTS AND DISCUSSION

Structure of PSC in the simulation and Energy level diagram of HTM free PSC device

The modeled PSC and band structure of the HTM free perovskite solar cell obtained with simulated parameters in Tables 1 and 2 are illustrated in Figure 1 (a) and (b). The interface conduction and valence band offset at the $\mathrm{TiO}_{2} / \mathrm{CH}_{3} \mathrm{NH}_{3} \mathrm{PbI}_{3}$ interface are $\Delta \mathrm{Ec}=0.31 \mathrm{eV}$ and $\Delta \mathrm{Ev}=2.02 \mathrm{eV}$ as shown in Figure $1(\mathrm{~b})$.

(a)

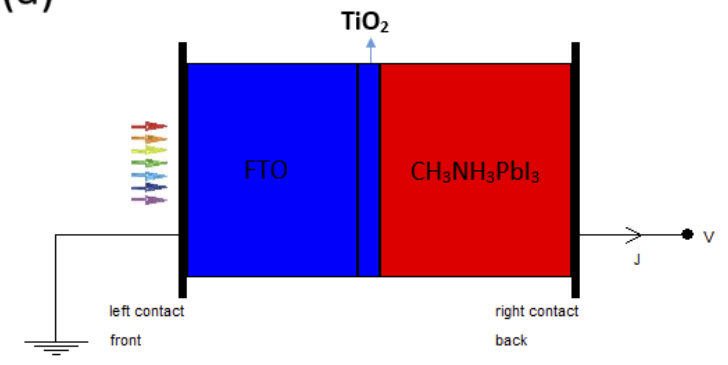

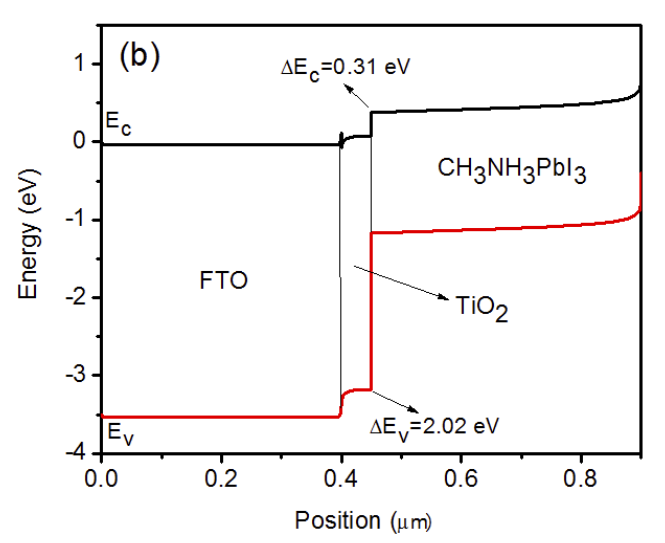

Figure 1. (a) The structure of perovskite solar cell in the simulation and (b) Energy band diagram of $\mathrm{TiO}_{2} / \mathrm{CH}_{3} \mathrm{NH}_{3} \mathrm{PbI}_{3} \mathrm{PSC}$ device.

The value of $\Delta \mathrm{Ec}$ prevents the flow of electron charge carrier from the electron transport layer to perovskite layer to the pt metal contact so as to avoid quenching in the perovskite layer. While the large value of $\Delta \mathrm{Ev}$ denies the flow of holes to the platinum-back contact to prevent their recombination with the electrons in the perovskite layer. These values 
can be seen important as they encouraged collection of charge carriers which results to higher photovoltaic performance in PSCs. As such, from the result of the band gap structure, $\mathrm{TiO}_{2}$ and $\mathrm{CH}_{3} \mathrm{NH}_{3} \mathrm{PbI}_{3}$ can form a p-n junction when combined together to be applied in photovoltaics.

\section{Performance parameters from initial simulation}

The J-V characteristics of the reference modeled PSC device under illumination and in the dark is shown in figure 2(a). Under illumination, a $\mathrm{J}_{\mathrm{sc}}$ of $21.96 \mathrm{mAcm}^{-2}$, Voc of $0.86 \mathrm{~V}$, FF of $69.94 \%$, and PCE of $13.22 \%$ are obtained. The $\mathrm{V}_{\mathrm{oc}}$ simulated in this studies agrees with $\mathrm{V}_{\mathrm{oc}}(0.85 \mathrm{~V})$ in experimental work demonstrated by a group of researchers [9]. However, the values of PCE, FF and $\mathrm{J}_{\mathrm{sc}}$ are higher than ones obtained from experimental research work, this may be due to the lesser series resistance arising from pt metal contact or FTO and the optical reflectance is considered to be zero at the surface and at each interface during our simulation [25].
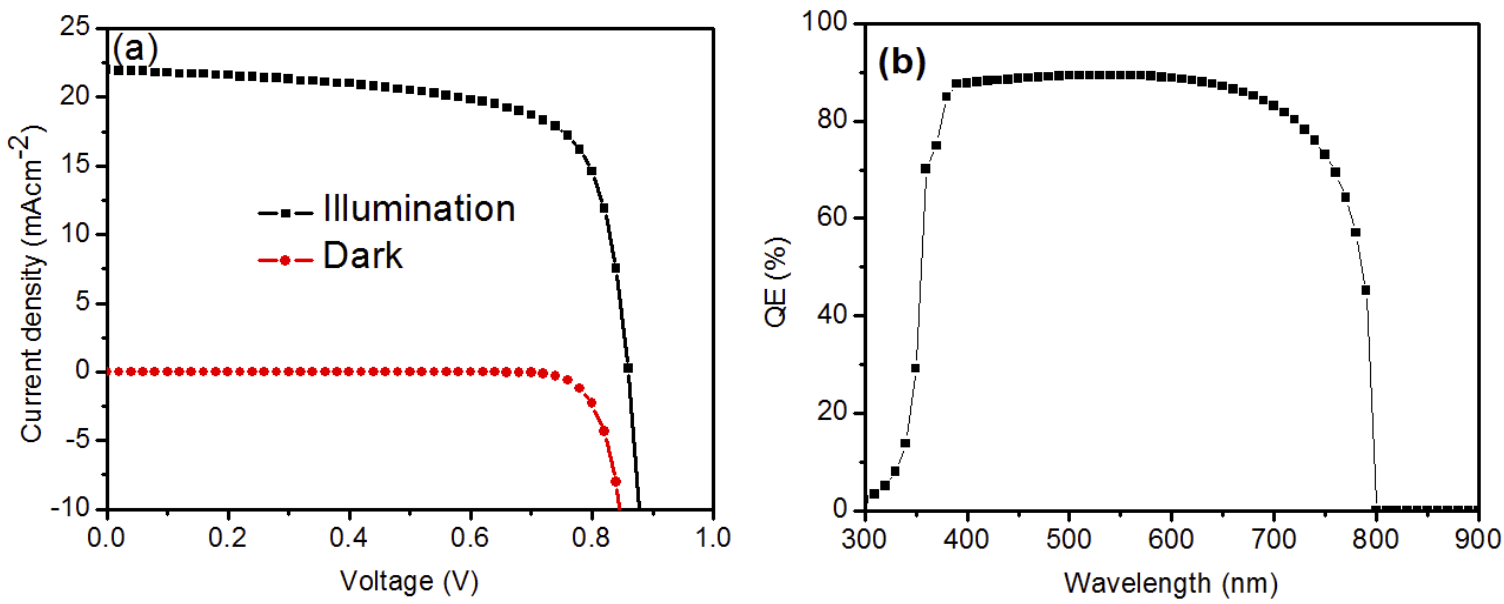

Figure 2. (a) J-V curve of PSC with initial parameters, (b) spectra of the device with initial parameters

As illustrated in Figure 2(a), Under the dark condition, there is no current flowing thereby behaving as a diode resulting to an extreme minimum value of $\mathrm{J}_{\mathrm{sc}}$ when the voltage is less than the knee voltage $(0.6 \mathrm{~V})$ and decreases gradually when the voltage further increases [25]. This results to rectifying characteristics and this rectifying behavior is a feature of photovoltaic devices and is a consequence of the asymmetric junction needed to separate charges.

In the quantum efficiency $(\mathrm{QE})$ of the device shown in figure 2 (b) which is within the wavelength of $300 \mathrm{~nm}$ and 900 $\mathrm{nm}$ has maximum attained value of $90 \%$ at $550 \mathrm{~nm}$. Optical absorption edge is red shifted to $800 \mathrm{~nm}$ which corresponds to a band gap of $1.55 \mathrm{eV}$ in $\mathrm{CH}_{3} \mathrm{NH}_{3} \mathrm{PbI}_{3}$. The $\mathrm{QE}$ sweeps across the whole visible spectrum which to an extent agrees with experimental work [9].

\section{Effect of thickness of Electron transport layer}

Figures 3(a), (b) and (c) show the J-V behavior, QE and the plot of solar cell parameters; $\mathrm{V}_{\mathrm{OC}}, \mathrm{J}_{\mathrm{SC}}, \mathrm{FF}$ and PCE versus thickness of the ETM. Thickness of ETM was varied from 0.02 to $0.10 \mu \mathrm{m}$. The results show that both the PCE, Jsc, Voc and FF decrease with the thickness of ETM. The slight decrease in the photovoltaic properties is due to fractional absorption of incident light by the $\mathrm{TiO}_{2}$ layer and the bulk/surface recombination at the interface which result to lesser electron and hole pairs extraction [26]. The decrease in FF is connected to the increase in series resistance.

Figure 3(b) displays the $\mathrm{QE}$ of the perovskite solar cell as a function of wavelength within the range of 300-900 nm with varied ETM layer thickness. It can be seen that the QE reaches a maximum value in the wavelength range of 380-570 $\mathrm{nm}$ and gradually decreases at longer wavelengths until $800 \mathrm{~nm}$, which corresponds to its absorption spectrum demonstrated in figure $3(\mathrm{~b})$. Table 3 shows the photovoltaic parameters obtained during the simulation.

Table 3. J-V characteristic parameters with the variation of thickness of ETM

\begin{tabular}{|c|c|c|c|c|}
\hline Parameters T $(\boldsymbol{\mu} \mathbf{~ m})$ & $\boldsymbol{J}_{\boldsymbol{s c}}\left(\mathbf{m A c m}^{-\mathbf{2}}\right)$ & $\boldsymbol{V}_{\boldsymbol{o c}} \mathbf{( V )}$ & $\boldsymbol{F F}$ & PCE $\mathbf{( \% )}$ \\
\hline 0.02 & 22.05 & 0.88 & 70.17 & 13.63 \\
0.03 & 22.01 & 0.87 & 70.11 & 13.40 \\
0.04 & 21.98 & 0.86 & 69.96 & 13.28 \\
0.05 & 21.96 & 0.86 & 69.94 & 13.22 \\
0.06 & 21.94 & 0.86 & 69.91 & 13.18 \\
0.07 & 21.93 & 0.86 & 69.91 & 13.17 \\
0.08 & 21.92 & 0.86 & 69.91 & 13.15 \\
0.09 & 21.90 & 0.86 & 69.91 & 13.15 \\
0.10 & 21.89 & 0.86 & 69.92 & 13.14 \\
\hline
\end{tabular}



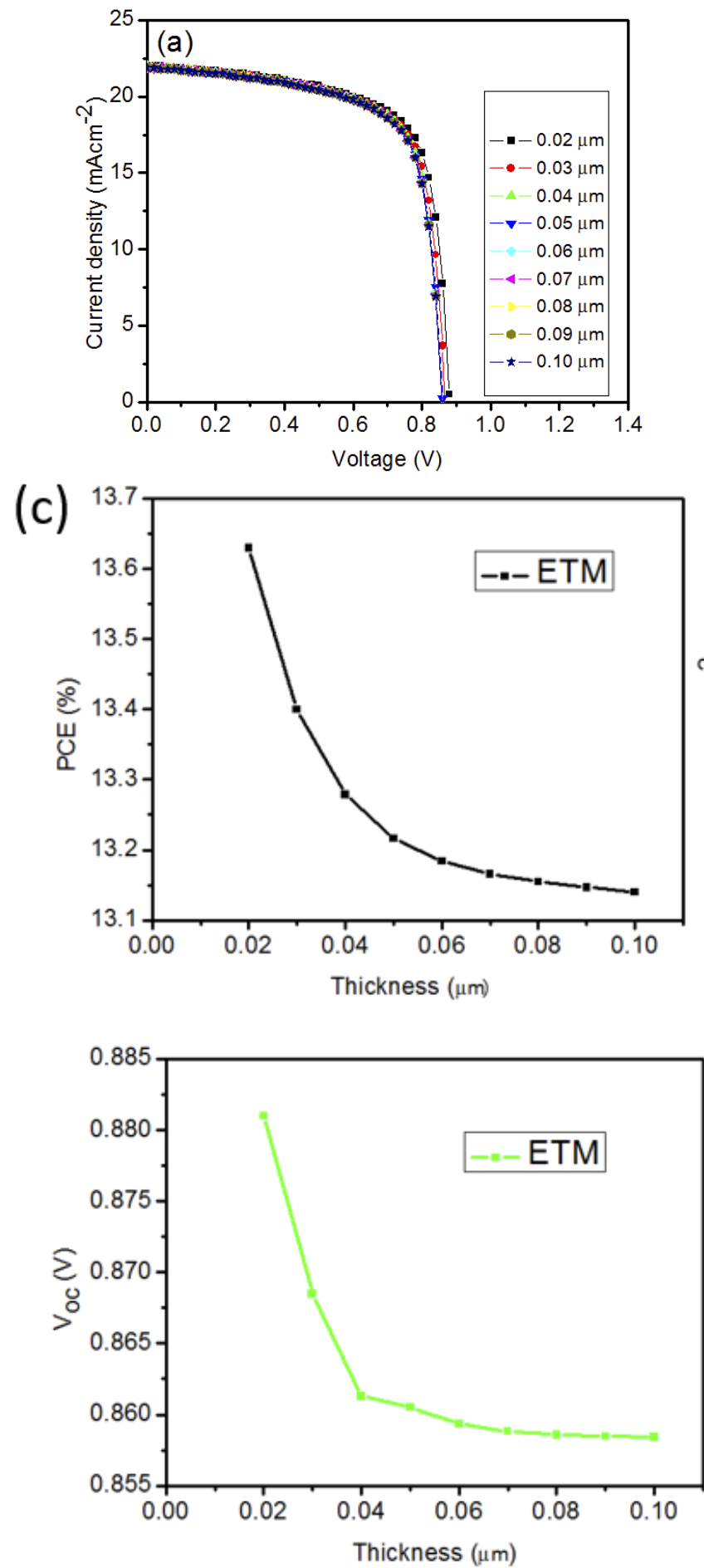
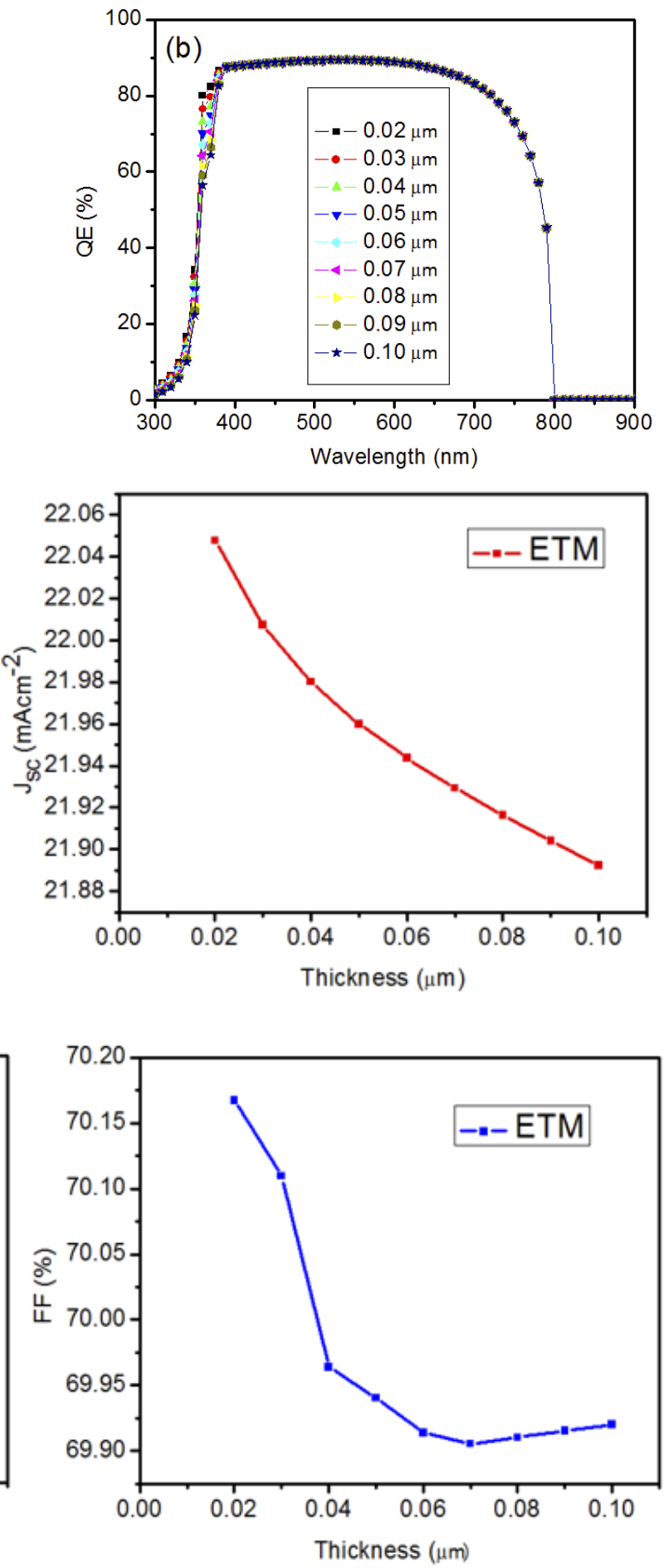

Figure 3. (a) J-V curves of PSC with different values of thickness of ETM, (b) QE with different values of thickness of ETM, (c) Variation in performance parameters of PSC with thickness of ETM.

\section{Effect of thickness of absorber layer}

The influence of thickness of absorber on the solar cell parameters; $\mathrm{V}_{\mathrm{OC}}, \mathrm{J}_{\mathrm{SC}}, \mathrm{FF}$ and PCE is shown in figure 4 (a). The J-V and QE of the varied absorber thickness is shown in Figure 4 (a) and (b).

As shown in Figure 4 (a), Jsc increases from 12.33 to $22.36 \mathrm{mAcm}^{-2}$ with thickness increase from 0.1 to 0.6 which is due to the increase in carrier generation and dissociation, then starts decreasing from 0.7 to $1.0 \mu \mathrm{m}$ which is attributed to high recombination rate within the range of the thickness. FF decreases slightly with thickness increase in the perovskite layer. Table 4 shows the photovoltaic parameters obtained during the simulation. The PCE increase with increase in layer thickness from 0.1 to $0.4 \mu \mathrm{m}$ due to the production of new charge carriers. However, PCE decreases from thickness of 0.5 to $1.0 \mu \mathrm{m}$ due to lesser electron and hole pairs extraction rate that leads to recombination process [27]. 
Figure 4 (c) exhibits the spectral response of the PSCs as a function of wavelength with varied $\mathrm{CH}_{3} \mathrm{NH}_{3} \mathrm{PbI}_{3}$ layer thickness within range of 300 to $900 \mathrm{~nm}$. The QE first increases rapidly with the $\mathrm{CH}_{3} \mathrm{NH}_{3} \mathrm{PbI}_{3}$ thickness increasing from 0.1 to $0.4 \mu \mathrm{m}$, and the QE increase slightly after the thickness is greater than $0.4 \mu \mathrm{m}$, which shows that $0.4 \mu \mathrm{m}$ thickness of $\mathrm{CH}_{3} \mathrm{NH}_{3} \mathrm{PbI}_{3}$ layer can absorb most of the incident photons and the part beyond $0.4 \mu \mathrm{m}$ can only contribute little to the PSC performance. Therefore, the optimized perovskite absorber layer thickness is around $0.4 \mu \mathrm{m}$ which gives $\mathrm{V}_{\mathrm{OC}}$ of $0.86 \mathrm{~V}, \mathrm{~J}_{\mathrm{SC}}$ of $21.63 \mathrm{mAcm}^{-2}$, FF of $71.39 \%$ and PCE of $13.21 \%$.
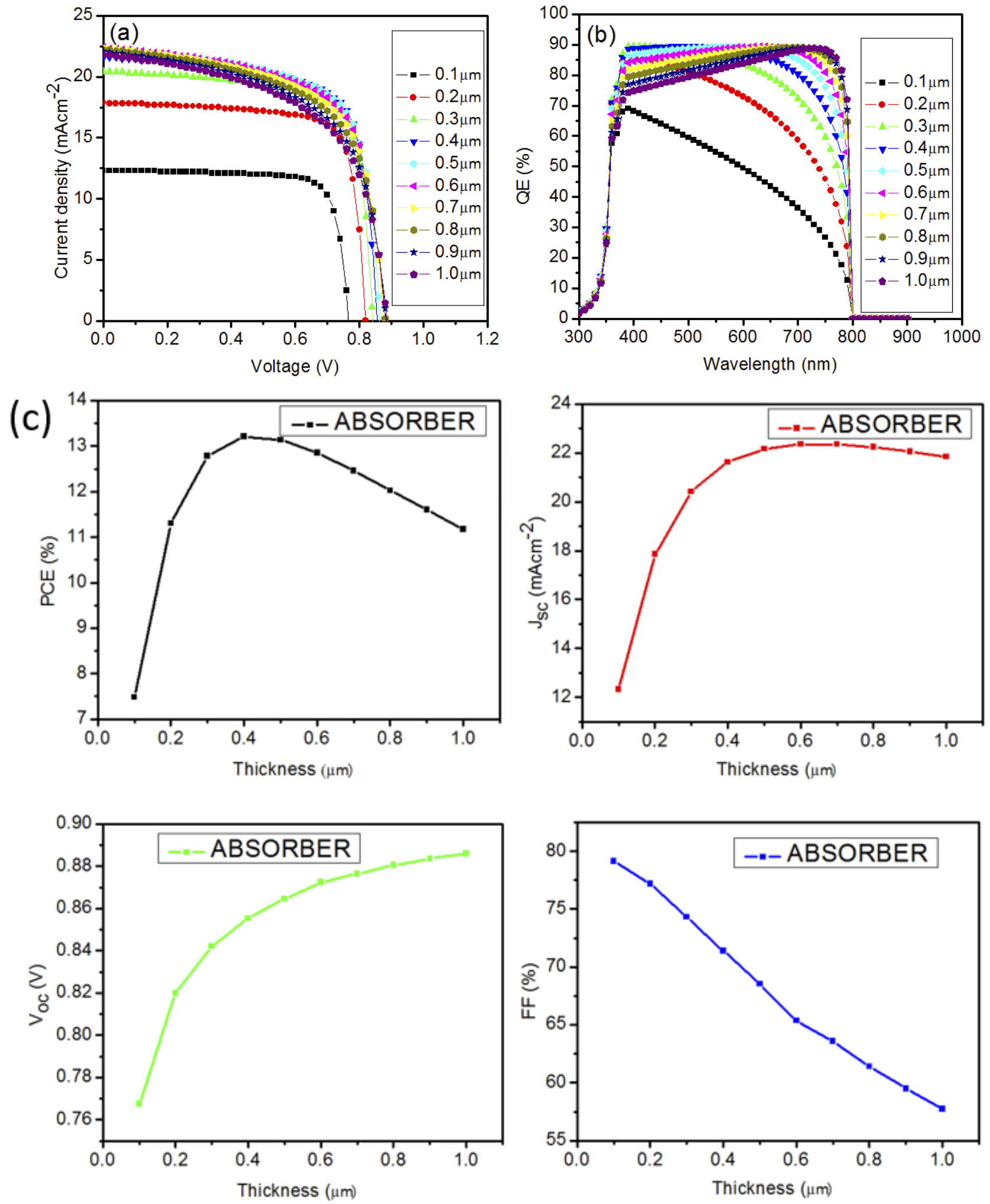

Figure 4. (a) J-V curves of PSC with different values of thickness of absorber layer, (b) QE with different values of thickness of absorber layer, (c) Variation in performance parameters of PSC with thickness of absorber layer 
Table 4. J-V characteristic parameters with the variation of thickness of absorber

\begin{tabular}{|c|c|c|c|c|}
\hline Parameters T $(\boldsymbol{\mu} \mathbf{~ m})$ & $\boldsymbol{J}_{\text {sc }}\left(\mathbf{m A c m}^{-\mathbf{2}}\right)$ & $\boldsymbol{V}_{\boldsymbol{o c}} \mathbf{( V )}$ & $\boldsymbol{F F}$ & PCE (\%) \\
\hline 0.1 & 12.34 & 0.77 & 79.12 & 7.48 \\
0.2 & 17.85 & 0.82 & 77.16 & 11.30 \\
0.3 & 20.42 & 0.84 & 74.32 & 12.78 \\
0.4 & 21.63 & 0.86 & 71.39 & 13.21 \\
0.5 & 22.17 & 0.86 & 68.54 & 13.13 \\
0.6 & 22.36 & 0.87 & 65.36 & 12.85 \\
0.7 & 22.36 & 0.88 & 63.59 & 12.46 \\
0.8 & 22.24 & 0.88 & 61.39 & 12.02 \\
0.9 & 22.06 & 0.88 & 59.50 & 11.60 \\
1.0 & 21.85 & 0.89 & 57.73 & 11.18 \\
\hline
\end{tabular}

Effect of doping concentration $\left(\mathrm{N}_{\mathrm{A}}\right)$ of absorber layer

Doping is the process of introducing impurities in absorber layer. The effect of doping concentration on the performance of perovskite solar cell is studied by choosing the values of $\mathrm{N}_{\mathrm{A}}$ in the range of $10^{10}-10^{17} \mathrm{~cm}^{-3}$ while keeping $\mathrm{N}_{\mathrm{D}}$ for ETM at $10^{17} \mathrm{~cm}^{-3}$. Table 5 gives the performance parameters of PSCs with various values of doping concentration. The highest value of PCE was obtained with doping concentration of $10^{16} \mathrm{~cm}^{-3}$ which shows value of $14.89 \%$. The highest value of fill factor was also observed at the same $\mathrm{N}_{\mathrm{A}}$. The PCE and the FF remained constant with increase in doping concentration from $10^{10}-10^{13} \mathrm{~cm}^{-3}$ and increases with doping concentration from $10^{13}-10^{16} \mathrm{~cm}^{-3}$. Beyond the values, a decrease in PCE and FF was noticed. The obtained results show that charge carriers are transported and collected optimally at the same irradiance when $\mathrm{N}_{\mathrm{A}}$ of the $\mathrm{CH}_{3} \mathrm{NH}_{3} \mathrm{PbI}_{3}$ is $1 \times 10^{16} \mathrm{~cm}^{-3}$. The $\mathrm{J}_{\mathrm{sc}}$ and Voc remained constant with increasing $\mathrm{N}_{\mathrm{A}}$ from $10^{10}-10^{13} \mathrm{~cm}^{-3}$, while beyond $10^{13} \mathrm{~cm}^{-3}, \mathrm{~J}_{\mathrm{sc}}$ increases with increasing $\mathrm{N}_{\mathrm{A}}$ and $\mathrm{V}_{\mathrm{oc}}$ decreases with increasing $\mathrm{N}_{\mathrm{A}}$. The ability of the photo-generated carriers is weak, resulting to a reduced Voc which caused a full depletion and strong electric field in the absorber layer.

The QE with respect to wavelength is as shown in Figure 5(b) with varied concentration from $10^{10}-10^{16} \mathrm{~cm}^{-3}$. It can be seen that the QE rapidly increase within the wavelength range of $300-380 \mathrm{~nm}$ and thereby maintained a constant until at $630 \mathrm{~nm}$ before it decreases rapidly to $800 \mathrm{~nm}$ from $10^{10}-10^{15} \mathrm{~cm}^{-3}$. From $10^{15}-10^{13} \mathrm{~cm}^{-3}$ a gradual decrease from the cutout of $390 \mathrm{~nm}$ until $800 \mathrm{~nm}$ was observed. The result shows that the solar cell functions effectively within the visible region.
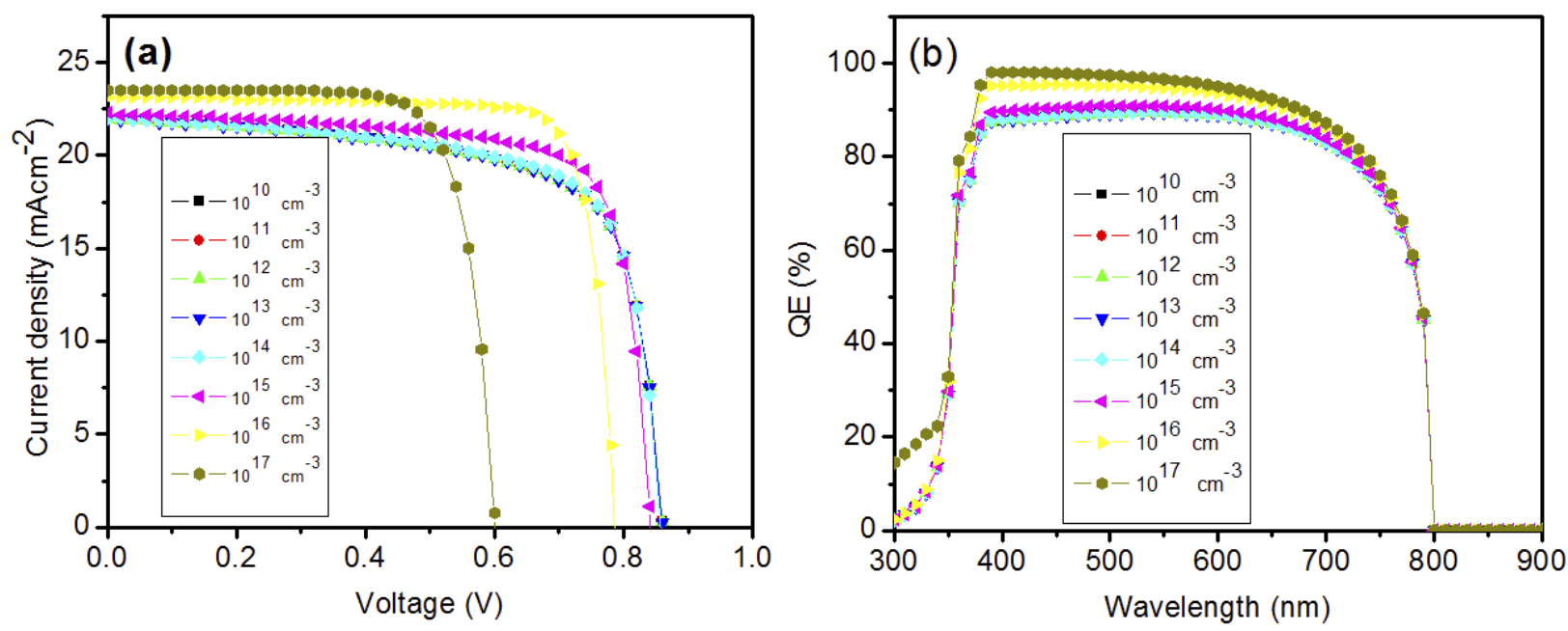

Figure 5. (a) J-V curves of PSC with different values of doping concentration in absorber layer, (b) QE with different values of doping concentration in absorber layer

Table 5. Dependence of solar cell performance on the doping concentration of Absorber layer

\begin{tabular}{|c|c|c|c|c|}
\hline Parameters $\mathrm{N}_{\mathrm{A}}\left(\mathrm{cm}^{-3}\right)$ & $J_{s c}\left(\mathrm{mAcm}^{-2}\right)$ & $V_{o c}(\mathbf{V})$ & $F F$ & PCE (\%) \\
\hline $1 \mathrm{E}+10$ & 21.96 & 0.86 & 69.86 & 13.20 \\
\hline $1 \mathrm{E}+11$ & 21.96 & 0.86 & 69.86 & 13.20 \\
\hline $1 \mathrm{E}+12$ & 21.96 & 0.86 & 69.87 & 13.20 \\
\hline $1 \mathrm{E}+13$ & 21.96 & 0.86 & 69.94 & 13.22 \\
\hline $1 \mathrm{E}+14$ & 22.00 & 0.86 & 70.65 & 13.34 \\
\hline $1 \mathrm{E}+15$ & 22.27 & 0.84 & 75.67 & 14.19 \\
\hline $1 \mathrm{E}+16$ & 23.13 & 0.79 & 81.85 & 14.89 \\
\hline $1 \mathrm{E}+17$ & 23.54 & 0.61 & 76.12 & 10.77 \\
\hline
\end{tabular}




\section{Effect of doping concentration ( $\left.\mathrm{N}_{\mathrm{D}}\right)$ of ETM}

The effect of doping concentration on the performance of perovskite solar cells is examined by varying the values of $\mathrm{N}_{\mathrm{D}}$ in the range of $10^{15}-10^{20} \mathrm{~cm}^{-3}$ while keeping $\mathrm{N}_{\mathrm{A}}$ for absorber at $10^{13} \mathrm{~cm}^{-3}$. Figure 6 (a) and (b) shows the $\mathrm{J}-\mathrm{V}$ curves of PSC with different values of doping concentration in ETM and QE with different values of doping concentration in ETM layer. When the doping concentration is varied from $10^{15}-10^{20} \mathrm{~cm}^{-3}$, it was depicted from Table 6 that, the PCE increased from $12.52 \%$ to $16.62 \%$. The increase in PCE is as a result of reduction in series resistance due to increase in optical conductivity of the ETM. Hence, the doping concentration $N_{D}$ is set at $10^{20} \mathrm{~cm}^{-3}$. Similarly, there was increase in other photovoltaic parameters $\left(\mathrm{J}_{\mathrm{sc}}, \mathrm{V}_{\mathrm{oc}}\right.$ and $\left.\mathrm{FF}\right)$ with increase in doping concentration values. The optimized values of the performance parameters are $\mathrm{PCE}=16.62 \%, \mathrm{Jsc}=22.24 \mathrm{mAcm}^{-2}$, Voc $=1.04 \mathrm{~V}$ and $\mathrm{FF}=72.18 \%$.

The increase in the photovoltaic parameters with increasing $\mathrm{N}_{\mathrm{D}}$ could be explained as follows: Auger recombination rate decreases with doping density below $10^{20} \mathrm{~cm}^{-3}$. It is seen that the quenching losses decreases when $\mathrm{N}_{\mathrm{D}}$ is below $10^{20}$ $\mathrm{cm}^{-3}$. We therefore speculate that, optimum doping concentration of ETM enhances the Voc and Jsc which subsequently results to higher PCE.
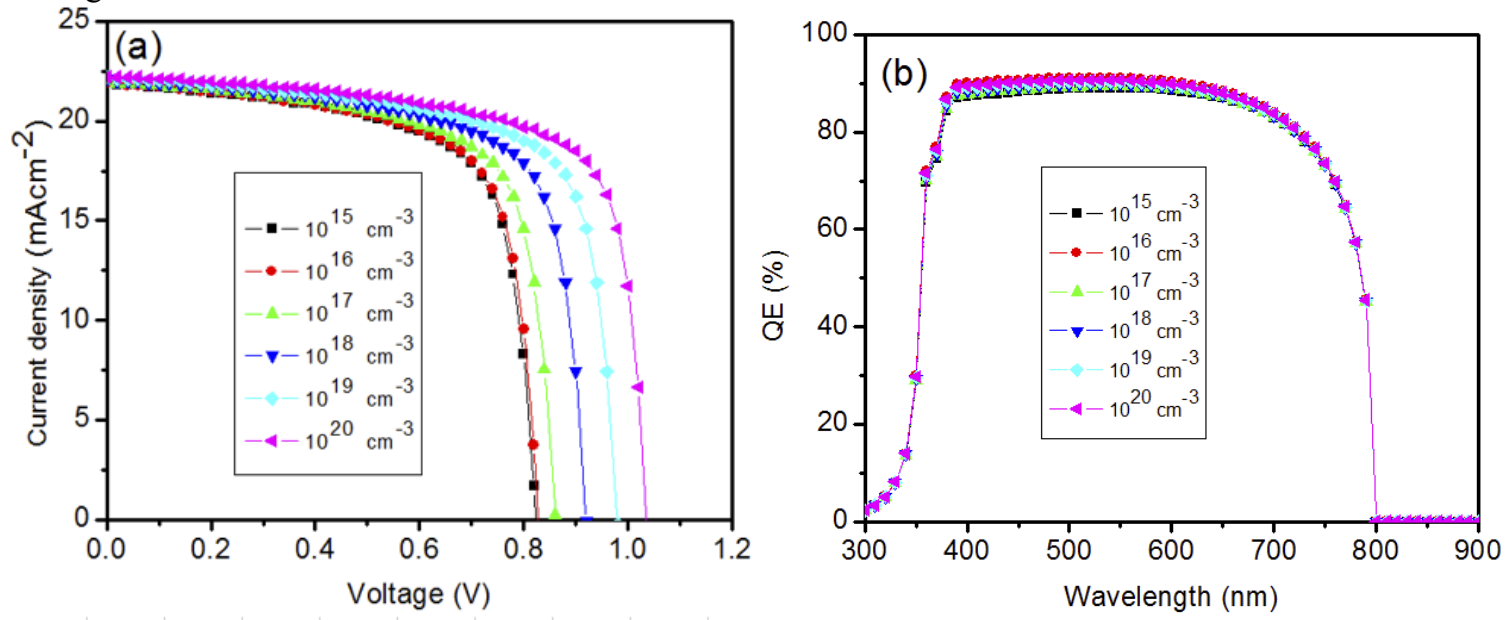

Figure 6. (a) the J-V curves of PSC with different values of doping concentration in ETM, (b) QE with different values of doping concentration in ETM layer

Table 6. Dependence of solar cell performance on the doping concentration of ETM

\begin{tabular}{|l|c|c|c|c|}
\hline Parameters $\mathbf{N}_{\mathbf{A}}\left(\mathbf{c m}^{-\mathbf{3}}\right)$ & $\boldsymbol{J}_{\mathbf{s c}}\left(\mathbf{m A c m}^{-\mathbf{2}}\right)$ & $\boldsymbol{V}_{\boldsymbol{~ o c}}(\mathbf{V})$ & $\boldsymbol{F F}$ & PCE (\%) \\
\hline $1 \mathrm{E}+15$ & 21.87 & 0.82 & 69.51 & 12.52 \\
$1 \mathrm{E}+16$ & 21.89 & 0.83 & 69.59 & 12.62 \\
$1 \mathrm{E}+17$ & 21.96 & 0.86 & 69.94 & 13.22 \\
$1 \mathrm{E}+18$ & 22.07 & 0.92 & 70.59 & 14.33 \\
$1 \mathrm{E}+19$ & 22.16 & 0.98 & 71.20 & 15.45 \\
$1 \mathrm{E}+20$ & 22.24 & 1.04 & 72.18 & 16.62 \\
\hline
\end{tabular}

\section{Influence of electron affinity of ETM}

The effect of electron affinity (EA) on the performance of perovskite solar cell is examined by varying the values of EA in the range of $3.7 \mathrm{eV}$ to $4.5 \mathrm{eV}$. Figure 7 (a), (b) and (c) shows the J-V curves of PSC with different values of EA of ETM, QE with different values of EA of ETM layer and Photovoltaic parameters with respect to EA.
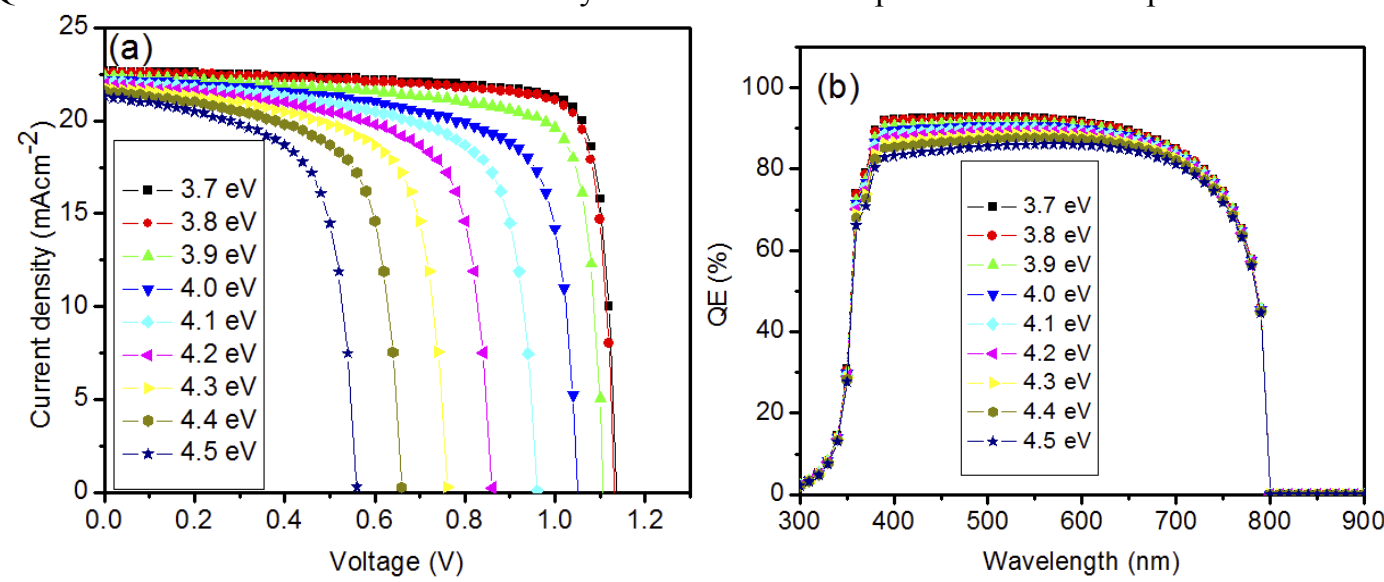

Figure 7. (a) J-V curves of PSC with different values of EA of ETM, (b) QE with different values of EA of ETM, (c) Variation in performance parameters of PSC with EA of ETM (continued on the next page) 

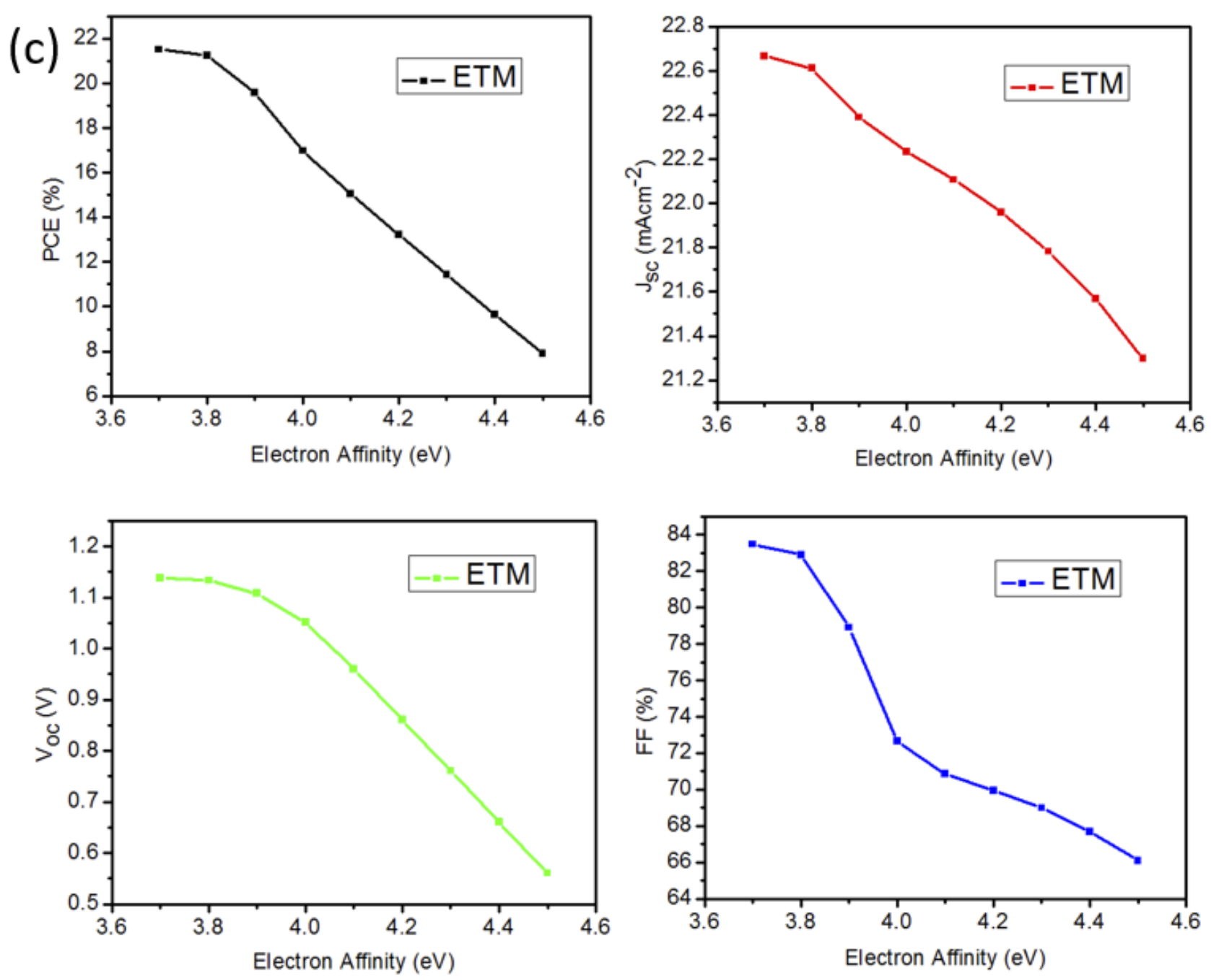

Figure 7. (a) J-V curves of PSC with different values of EA of ETM, (b) QE with different values of EA of ETM, (c) Variation in performance parameters of PSC with EA of ETM

Figures 7(c) shows variation of PCE, Voc, Jsc and FF with electron affinity of ETM and figure 7(a) show the J-V curve with different electron affinity values. The optimum photovoltaic performance was obtained at EA value of $3.7 \mathrm{eV}$, which gave PCE, Jsc, Voc and FF as shown in Table 7. It is now evident from our findings that proper selection ETM with good EA can reduce quenching losses in PSCs. Table 7 gives the performance parameters of PSCs with various values of EA.

Table 7. Dependence of solar cell performance on the electron affinity of ETM

\begin{tabular}{|c|c|c|c|c|}
\hline Parameters EA $(\mathbf{e V})$ & $\boldsymbol{J}_{\boldsymbol{s c}}\left(\mathbf{m A c m}^{-\mathbf{2}}\right)$ & $\boldsymbol{V}_{\boldsymbol{o c}}(\mathbf{V})$ & $\boldsymbol{F F}$ & PCE (\%) \\
\hline 3.7 & 22.67 & 1.14 & 83.49 & 21.53 \\
3.8 & 22.61 & 1.13 & 82.90 & 21.24 \\
3.9 & 22.39 & 1.11 & 78.90 & 19.58 \\
4.0 & 22.23 & 1.05 & 72.65 & 16.98 \\
4.1 & 22.10 & 0.96 & 70.86 & 15.04 \\
4.2 & 21.96 & 0.86 & 69.94 & 13.22 \\
4.3 & 21.78 & 0.76 & 69.00 & 11.43 \\
4.4 & 21.57 & 0.66 & 67.69 & 9.64 \\
4.5 & 21.30 & 0.56 & 66.10 & 7.89 \\
\hline
\end{tabular}

Performance of PSC with Optimized parameters

After simulating the PSC, the ETM thickness, absorber thickness, doping concentration of absorber and ETM were optimized and the values are as shown in Table 8(a). The final optimized PSC gave a PCE of $25.75 \%$, Jsc of 23.25 $\mathrm{mAcm}^{-2}$, Voc of $1.24 \mathrm{~V}$ and FF of $89.50 \%$. When the optimized result is compared with the reference initial device, an improvement of $\sim 1.95$ times in PCE, 1.06 times in Jsc, $\sim 1.44$ times in Voc and $\sim 1.28$ times in FF is obtained over the 
device that was not optimized. The behaviour of the JV curve in the dark and under illumination is as shown in figure 8(a). Experimental work of HTM free PSC published by other researchers are compared with the simulated results and summarized in Table $8(b)$.

In the experimental works, PCEs of 3.80 and $4.2 \%$ were achieved for HTM free PSCs with $\mathrm{TiO}_{2}$ as ETM. The photovoltaic parameters could be improved further to realize the high photovoltaic values achieved in the simulation. This could be realized by improving the film quality of both the absorber and ETM and also consider proper doping of the absorber and ETM in order to realize good electron density.

The energy diagram of the optimized device is as shown in figure 8(c). From the band structure, the conduction and valence band offset at the $\mathrm{TiO}_{2} / \mathrm{CH}_{3} \mathrm{NH}_{3} \mathrm{PbI}_{3}$ interface were reduced to $0.06 \mathrm{eV}$ and $1.98 \mathrm{eV}$, which can be considered beneficial for the flow of photo-excited charge carriers to the front electrode and back-metal contact in order to avoid their recombination and quenching losses. The quantum efficiency also shows stronger absorber in the visible region as compared to the device without optimization as shown in figure 8(b).
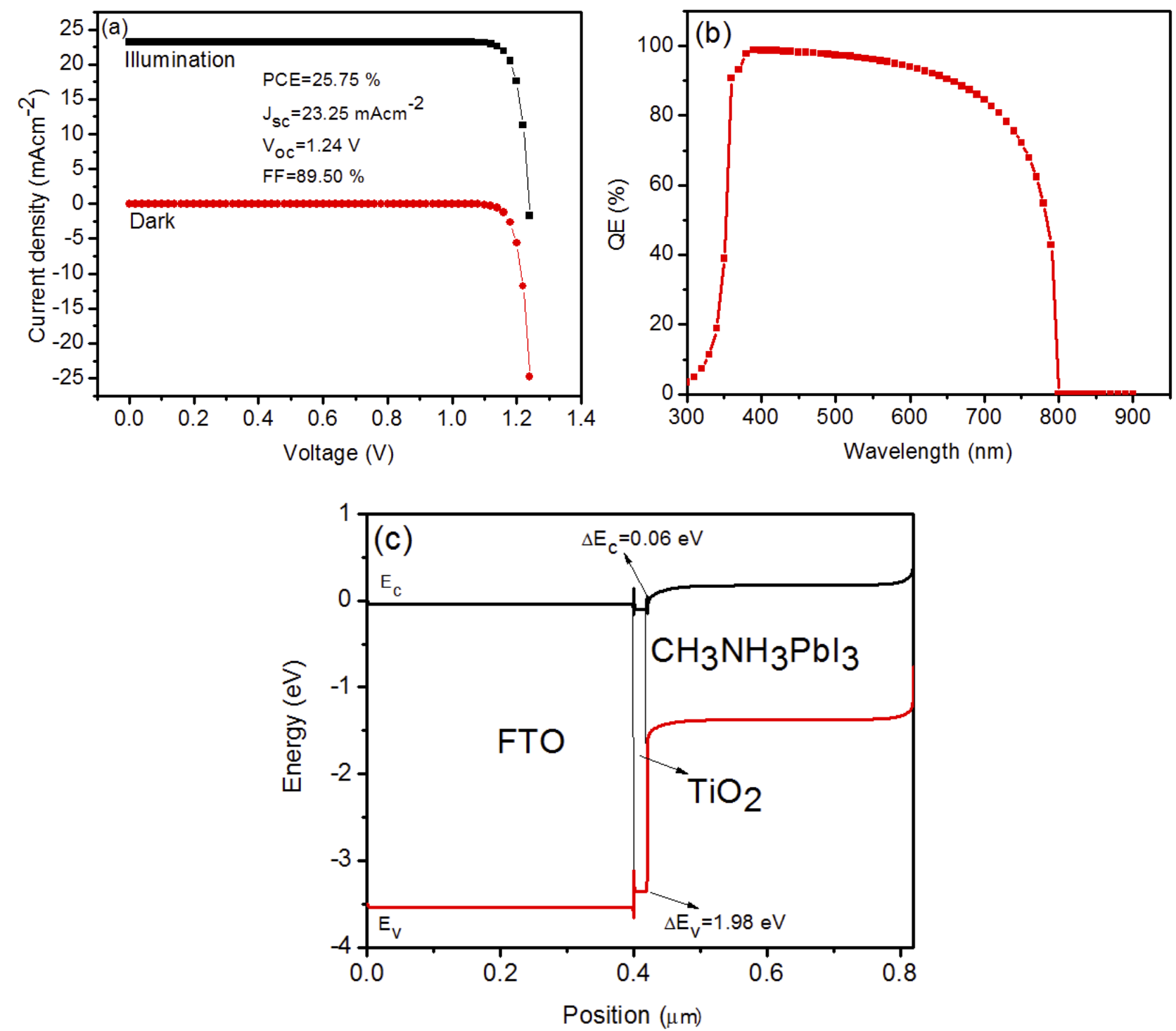

Figure 8. (a) J-V curves of PSC with Optimized parameters, (b) QE with optimized parameters and (c) Energy band diagram of $\mathrm{TiO}_{2} / \mathrm{CH}_{3} \mathrm{NH}_{3} \mathrm{PbI}_{3} \mathrm{PSC}$ device

Table 8. (a) Optimized Parameters of the device

\begin{tabular}{|l|c|c|}
\hline \multicolumn{1}{|c|}{ Optimized parameters } & ETM (TiO2) & $\begin{array}{c}\text { Absorber } \\
(\mathrm{CH} 3 \mathrm{NH} 3 \mathrm{~Pb} 33)\end{array}$ \\
\hline Thickness $(\mu m)$ & 0.02 & 0.40 \\
Doping density $\left(\mathrm{N}_{\mathrm{A}}\right)\left(\mathrm{cm}^{-3}\right)$ & -- & $1 \mathrm{E}+16$ \\
Doping density $(\mathrm{ND})\left(\mathrm{cm}^{-3}\right)$ & $1 \mathrm{E}+20$ & -- \\
Electron Affinity $(\mathrm{EA})$ & 3.7 & -- \\
\hline
\end{tabular}


Table 8(b). Photovoltaic parameters of HTM free perovskite solar cells reported in the experimental work in the literature and simulated results using SCAPS.

\begin{tabular}{|l|c|c|c|c|}
\hline \multicolumn{1}{|c|}{ Simulation } & $\boldsymbol{J}_{\text {sc }}\left(\mathbf{m A c m}^{-\mathbf{2}}\right)$ & $\boldsymbol{V}_{\boldsymbol{o c}}(\mathbf{V})$ & $\boldsymbol{F F}$ & PCE (\%) \\
\hline Initial & 21.96 & 0.86 & 69.94 & 13.22 \\
Optimized N $\mathrm{N}_{\mathrm{A}}$ of absorber & 23.13 & 0.79 & 81.85 & 14.89 \\
Optimized ND of ETM & 22.24 & 1.04 & 72.18 & 16.62 \\
Optimized thickness of absorber & 21.63 & 0.86 & 71.39 & 13.21 \\
Optimized EA of ETM & 22.67 & 1.14 & 83.49 & 21.53 \\
Optimized thickness of ETM & 22.05 & 0.88 & 70.17 & 13.63 \\
Final Optimization & 23.25 & 1.24 & 89.50 & 25.75 \\
[9] & 11.04 & 0.85 & 41.00 & 3.80 \\
[28] & 13.60 & 0.67 & 45.80 & 4.20 \\
\hline
\end{tabular}

\section{CONCLUSION}

In this work, the HTM free PSC was investigated systematically using Solar Cell Capacitance Simulator (SCAPS-1D) program. The photovoltaic performance of the modeled device with various $\mathrm{CH}_{3} \mathrm{NH}_{3} \mathrm{PbI}_{3}$ thicknesses, ETM thicknesses, ETM electron affinities, ETM doping concentrations and $\mathrm{CH}_{3} \mathrm{NH}_{3} \mathrm{PbI}_{3}$ doping concentrations, has been analyzed. From the obtained results, it is found that the parameters affect the performance of the solar cell. The overall PCE, FF, Jsc, and Voc, of $25.75 \%, 89.50 \%, 23.25 \mathrm{mAcm}^{-2}$, and $1.24 \mathrm{~V}$ respectively were obtained by using all optimised parameters.

\section{ACKNOWLEDGMENTS}

The authors would like to thank Professor Marc Burgelman, Department of Electronics and Information Systems, University of Ghent for the development of the SCAPS software package and for allowing its use.

\section{ORCID IDs}

DEli Danladi, https://orcid.org/0000-0001-5109-4690

\section{REFERENCES}

[1] J.S. Manser, and P.V. Kamat, Nature Photonics, 8, 737-747 (2014), https://doi.org/10.1038/nphoton.2014.171.

[2] H. Chen, F. Ye, W. Tang, J. He, M. Yin, Y. Wang, F. Xie, E. Bi, X. Yang, and M. Gratzel, L. Han, Nature, 550, 92-95 (2017), https://doi.org/10.1038/nature23877.

[3] G. Xing, N. Mathews, S. Sun, S.S. Lim, Y. M. Lam, M. Gratzel, S. Mhaisalkar, and T.C. Sum, Science, 342, 344-347 (2013), https://doi.org/10.1126/science.1243167.

[4] M. Liu, M. B. Johnston, and H. J. Snaith, Nature, 501, 395-398 (2013), https://doi.org/10.1038/nature12509.

[5] Z. Wang, Q. Lin, F.P. Chmiel, N. Sakai, L.M. Herz, and H.J. Snaith, Nature Energy, 2, 17135 (2017), https://doi.org/10.1038/nenergy.2017.135.

[6] Y. Liu, Z. Yang, D. Cui, X. Ren, J. Sun, X. Liu, J. Zhang, Q. Wei, H. Fan, F. Yu, X. Zhang, C. Zhao, and S. Liu, Advanced Materials, 27, 5176-5183 (2015), https://doi.org/10.1002/adma.201502597.

[7] D. Yang, Z. Yang, W. Qin, Y. Zhang, S. Liu, and C. Li, Journal of Materials Chemistry A, 3, 9401-9405 (2015), https://doi.org/10.1039/C5TA01824B.

[8] A. Kojima, K. Teshima, Y. Shirai, and T. Miyasaka, Journal of the American Chemical society, 131(17), 6050-6051 (2009), https://doi.org/10.1021/ja809598r.

[9] D. Eli, M. Y. Onimisi, S. Garba, and J. Tasiu, SN Applied Sciences, 2, 1769 (2020), https://doi.org/10.1007/s42452-020-03597-y.

[10] N. Rajamanickam, S. Kumari, V. K. Vendra, B. W. Lavery, J. Spurgeon, T. Druffel, and M.K. Sunkara, Nanotechnology, 27, 235404 (2016), https://doi.org/10.1088/0957-4484/27/23/235404.

[11] K.G. Lim, H.B. Kim, J. Jeong, H. Kim, J.Y. Kim, and T.W. Lee, Advanced Materials, 26, 6461-6466 (2014), https://doi.org/10.1002/adma.201401775.

[12] D. Wang, M. Wright, N.K. Elumalai, and A. Uddin, Solar Energy Materials and Solar Cells, 147, $255-275$ (2016), https://doi.org/10.1016/j.solmat.2015.12.025.

[13] L. Etgar, P. Gao, Z. Xue, Q. Peng, A.K. Chandiran, B. Liu, M.K. Nazeeruddin, and M. Gratzel, Journal of the American Chemical Society, 134, 17396-17399 (2012), https://doi.org/10.1021/ja307789s.

[14] Z. Li, S.A. Kulkarni, P.P. Boix, E. Shi, A. Cao, K. Fu, S.K. Batabyal, J. Zhang, Q. Xiong, L.H. Wong, N. Mathews, and S.G. Mhaisalkar, ACS nano, 8, 7, 6797-6804 (2014), https://doi.org/10.1021/nn501096h.

[15] X. Zhang, Y. Zhou, Y. Li, J. Sun, X. Lu, X. Gao, J. Gao, L. Shui, S. Wu, and J-M. Liu, Journal of materials chemistry C, 7, 3852-3861 (2019), https://doi.org/10.1039/C9TC00374F.

[16] L. Lin, L. Jiang, Y. Qiu, and Y. Yu, Superlattices and Microstructures, 104, 167-177 (2017), https://doi.org/10.1016/j.spmi.2017.02.028.

[17] T. Wang, J. Chen, G. Wu, and M. Li, Science China Materials, 59(9), 703-709 (2016), https://doi.org/10.1007/s40843-016-5108-4.

[18] Haynes, W (Ed), CRC handbook of chemistry and physics, 97 $7^{\text {th }}$ ed. (CRC press, New York, 2017).

[19] S.Z. Haider, H. Anwar, and M. Wang, Semicond. Sci. Technol. 33(3), 035001 (2018), https://doi.org/10.1088/1361-6641/aaa596.

[20] R Wei, M.Sc Degree Thesis, Queensland University of Technology, 2018.

[21] U. Mandadapu, S.V. Vedanayakam, and K. Thyagarajan, Indian Journal of Science Technology, 10(11), 1-8 (2017), https://www.researchgate.net/profile/Victor-Vedanayakam-

2/publication/316484058_Simulation_and_Analysis_of_Lead_based_Perovskite_Solar_Cell_using_SCAPS-

1D/links/5a8afb1 caca272017e639098/Simulation-and-Analysis-of-Lead-based-Perovskite-Sölar-Cell-using-SCAPS-1D.pdf. 
[22] M. Amalina, and M. Rusop, World Journal of Engineering, 9, 251-256 (2012), https://doi.org/10.1260/1708-5284.9.3.251.

[23] D. Eli, M. Y. Onimisi, S. Garba, R. U. Ugbe, J. A. Owolabi, O. O. Ige, G. J. Ibeh, and A. O. Muhammed, Journal of the Nigerian Society of Physical Sciences, 1, 72-81, (2019), https://doi.org/10.46481/jnsps.2019.13.

[24] M. I. Hossain, F. H. Alharbi, and N. Tabet, Solar Energy, 120, 370-380 (2015), https://doi.org/10.1016/j.solener.2015.07.040.

[25] L, Lin, L, Jiang, Y, Qiu, and Y. Yu, Superlattices and Microstructures, 104, 167-177 (2017), https://doi.org/10.1016/j.spmi.2017.02.028.

[26] P. Gao, M. Gratzel, and M. K. Nazeeruddin, Energy and Environmental Science, 7, 2448-2463 (2014), https://doi.org/10.1039/C4EE00942H.

[27] U. Mandadapu, S.V. Vedanayakam, and K. Thyagarajan, Int. J. Eng. Sci. Invention, 2,40-45 (2017).

[28] W. Liu, and Y. Zhang, Journal of materials chemistry A, 2, 10244-10249 (2014), https://doi.org/10.1039/C4TA01219D.

\section{ЧИСЛЕННЕ МОДЕЛЮВАННЯ ТА АНАЛІЗ ГЕТЕРОПЕРЕХІДНОГО СОНЯЧНОГО ЕЛЕМЕНТА БЕЗ НТМ 3 ВИКОРИСТАННЯМ ПРОГРАМИ SСАРS-1D \\ Елі Данладіа \\ а Факультет фізичних наук, Університет Грінфілд, Кадуна, Нігерія \\ ${ }^{b}$ Фізичний факультет, Державний університет Кадуни, Кадуна, Нігерія}

У цій дослідницькій роботі пропонується структура перовскітного сонячного елемента (PSC), що не містить НТМ (дірковотранспортувальний матеріал), 3 титаном $\left(\mathrm{TiO}_{2}\right)$, метил-амонієвим трийодидом свинцю $\left(\mathrm{CH}_{3} \mathrm{NH}_{3} \mathrm{PbI}_{3}\right)$ i платиною $(\mathrm{Pt})$ в якості електронно-транспортного матеріалу (ЕTM), збирача фотонів та металевого зворотного контакту. Для реалізації моделі та моделювання була використана програма «Імітатор Смності Сонячних Елементів» (SCAPS-1D). Проводилось системне дослідження впливу таких параметрів як товщина ETM, товщина поглинача, концентрація легуючих речовин ЕTM та поглинача, а також спорідненість до електронів (ЕА) електронно-транспортного матеріалу (ЕТМ). 3 отриманих результатів було встановлено, що ці параметри впливають на продуктивність сонячного елемента. Коли товщина ЕТМ змінювалась від 0,02 до $0,10 \mu m$, результати показали, що фотоелектричні параметри зменшуються із збільшенням товщини. Коли товщина поглинача змінювалася від 0,1 до $1,0 \mu m$, оптимізоване значення було встановлено при товщині $0,4 \mu m$. Коли концентрація легуючих речовин поглинача та ЕМТ змінювалась від $10^{10}-10^{17} \mathrm{~cm}^{-3}$ та від $10^{15}-10^{20} \mathrm{~cm}^{-3}$, найвищі значення РСЕ (ефективність перетворення потужності) були отримані при $10^{16} \mathrm{~cm}^{-3}$ та $10^{20} \mathrm{~cm}^{-3}$ для поглинача та ЕТМ. Також, коли ЕА (спорідненість до електронів) змінювалась в діапазоні від 3,7 до 4,5 еВ, оптимізоване значення було на рівні 3,7 еВ. Після оптимізації вищезазначених параметрів було встановлено, що ефективність перетворення потужності (РСЕ) становить: 25,75\%,25,75\%, щільність струму короткого замикання $\left(\mathrm{J}_{\mathrm{sc}}\right)-23,25$ мАсм$^{-2}$, напруга розімкнутого контуру $\left(\mathrm{V}_{\mathrm{oc}}\right)-1,24 \mathrm{~B}$, і коефіцієнт заповнення (FF) - 89,50\%. Оптимізований результат показує підвищення РСЕ в $\sim 1,95$ разів, $\mathrm{J}_{\mathrm{sc}}$ в $\sim 1,06$ разів, $\mathrm{V}_{\text {oc }}$ в 1,44 рази $\mathrm{i} \mathrm{FF}$ в $\sim 1,28$ разів порівняно 3 початковим пристроєм із наступними параметрами, $\mathrm{PCE}=13,22 \%, \mathrm{~J}_{\mathrm{sc}}=21,96 \mathrm{mAcm}^{-2}$, $\mathrm{V}_{\mathrm{oc}}=0,86 \mathrm{~B}$ i $\mathrm{FF}=69,94 \%$.

КЛЮЧОВІ СЛОВА: перовскітний сонячний елемент, без НТМ (дірково-транспортувальний матеріал), моделювання пристроїв, імітація, зміщення забороненої зони 